\title{
Programme elements of Swedish nuclear waste management - implementing with what results?
}

\author{
Ulf Roßegger \\ Chair in Public Law and \\ Administrative Sciences, \\ Technical University \\ of Braunschweig, \\ Bienroder Weg 87, \\ D-38106 Braunschweig, \\ Germany \\ E-mail:u.rossegger@tu-bs.de
}

In the controversy over a safe and permanent disposal of nuclear waste, numerous solutions have been put forward. While from a scientific point of view answers are inconclusive, the option of geological disposal seems to be the most common approach in several European countries, i. e. in Sweden.

Firstly, the objective of this article is to present the organisation of nuclear waste management (NWM) in Sweden. The particular focus shall be put on the implementation of the respective national policy. Furthermore, it will be shown what kind of responsible agencies were established. The article aims at analysing the adopted strategy and process as well as showing the difficulties inherent to finding a site which is both appropriate and meets technical issues, political and public acceptance.

After a short outline of the historical development the article attempts to identify special national phases in the development of the nuclear waste management. It then illustrates how the Swedish national concept for the direct geological disposal of domestic nuclear fuel has been implemented and which policy regimes have been introduced. In addition to that, the present situation or stage of implementing will be analysed.

Key words: Nuclear Waste Management, high-level waste, Sweden

\section{CURRENT SITUATION}

Several European countries with nuclear power favour the option of geological disposal as the best option [1]. A high potential for conflicts arises on how to find a site and siting strategies that are politically and publicly acceptable. For a long time Sweden has seemed to implement its policy for nuclear waste management successfully. The article shows how the Swedish nuclear waste management (NWM) process is running up-to-date.

All over the world countries are meeting problems when nuclear waste management policies were implemented. The main hypothesis of the article is that technical and society conflicts are often settled within the phase of im- plementation. Furthermore, it is debatable to what extent the principle of countervailing influence - top-down-process versus bottom-up-process - is an explaining factor. An integration of various stages and actors could be understood as a driver and simultaneously as a catalyser for the whole process. The research of implementation has shifted its contents from the consideration of effectiveness to the importance of implementation for policy legitimation.

With regard to NWM the governmental and administrative action has to produce an outcome. Nevertheless, functionality resists as a central feature to assure quality management and to supervise the accomplishment of duties and responsibilities. The role of referring to scientific findings and the extent of private enterprises actions in this 
process have been analysed. An adaptation is easier when a formulated policy is put into practice than to handle with negotiations and substantial changes [2].

In general, a strategy has to be consistent to pave the way for locating the final disposal for spent nuclear fuel. Due to this argument some key elements have to be taken into account: (a) scientific paradigm, (b) environmental and economical cost-benefit-analyses, (c) the political (and) popular dimension of environmental protection, and (d) public participation in environmental decision making. An integrated approach considers the technical side of the problem to dispose nuclear waste, the societal and political dimension as well as the legal basis and other framework requirements [3].

\section{RESEARCH IMPLEMENTATION}

The methodology is based on the approach of research implementation and the question is about possible causes for discrepancy between the norm (action programme) and reality (impact), when programme implementation is forced by orders, other rules or current findings and how an operational process will be organized as a definitive factor. A further side effect is to evaluate success or fail elements of the process. The aim is to come to general evidence on terms and conditions exercised at political stage [4].

The structure and useful tool of an implementation process can be seen below in Fig. 1. First, there is the tractability of the problem (here: disposal of spent nuclear fuel). This content will bring about two variables: (1) the ability of statute to structure implementation and (2) nonstatutory variables affecting implementation.

As defined by Sabatier and Mazmanian [4], the most important conditions of effective implementation are the following:

- The programme is based on sound theory.

- The statute contains clear policy directives.

- Leaders possess substantial managerial and political skill.

- The programme is actively supported by constituent groups.

- Relative priority of statutory objectives is not undermined.

For handling an issue there is the importance and tractability of a problem and additionally how actors are dealing with it. To structure an implementation the following items have to be taken into account: (1) coherent objectives are existing, (2) incorporation of a useful and causal theory, (3) availability of financial resources, (4) hierarchical integration orientated on institutions, (5) existence of decision-rules of implementing agencies, (6) identification or recruitment of implementing officials and (7) granting formal access by outsiders.

These aspects will have an impact on the success of programme implementation. Nevertheless, "difficulties" exist in measuring changes in the seriousness of the issue.

The interaction between the technical and the societal context is therefore a basic assumption when nuclear waste management processes will be implemented.

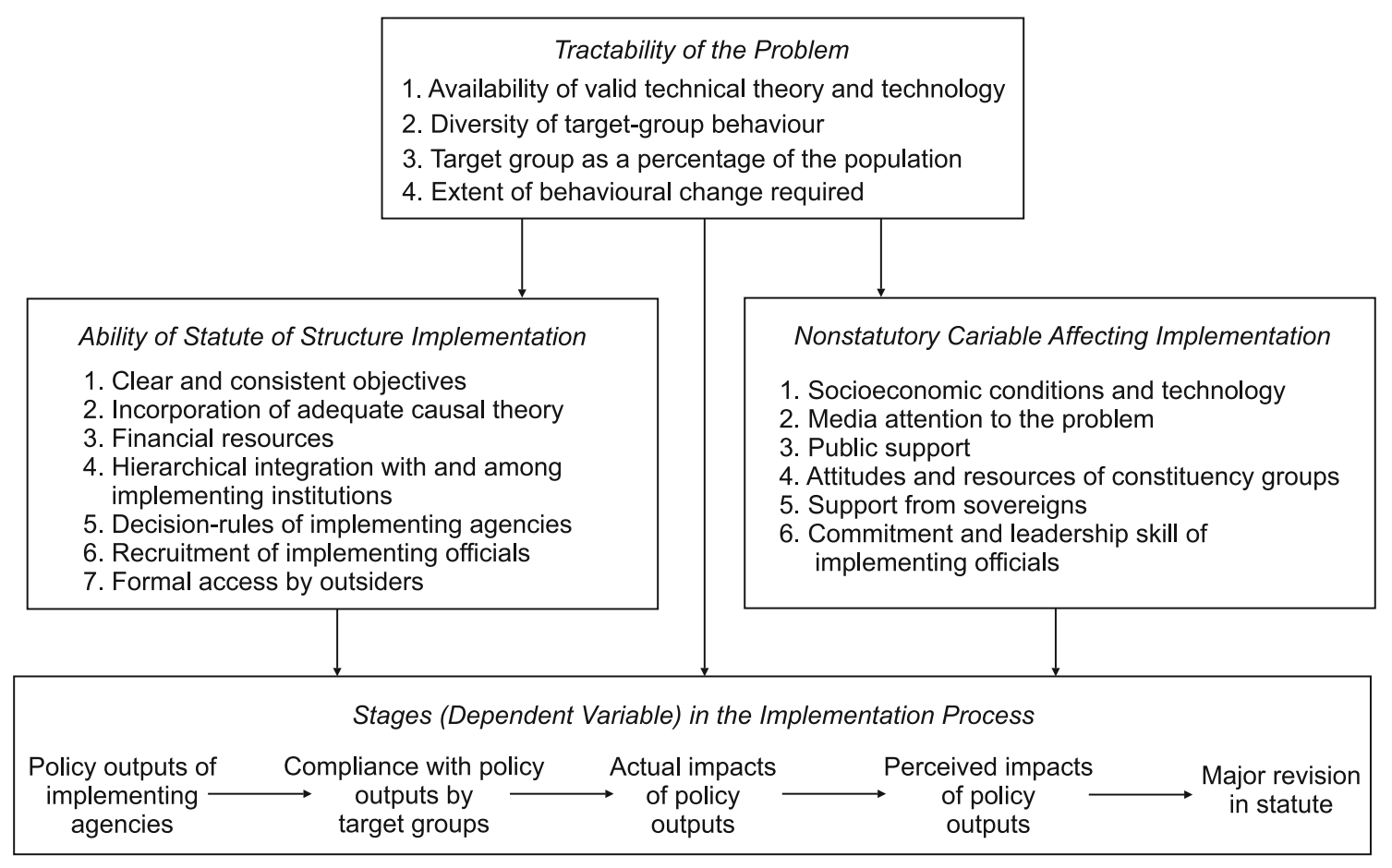

Fig. 1. Skeletal Flow Diagram of the Variables involved in the Implementation Process [4] 


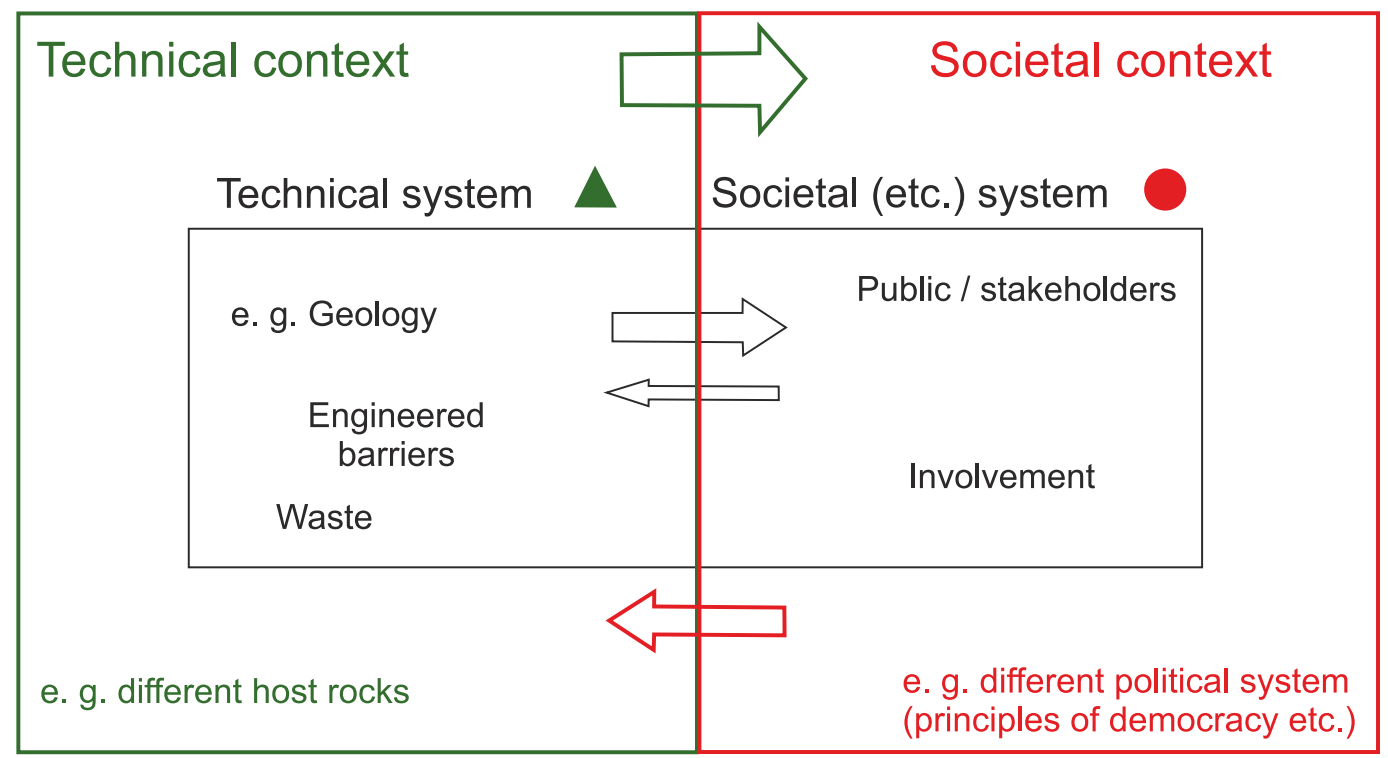

Fig. 2. Radioactive waste governance in the (geo-)technical and socio-cultural context [3]

\section{HISTORICAL ASPECTS OF SWEDISH NUCLEAR WASTE MANAGEMENT}

In Sweden, the operators have the responsibility of dispose and final disposal of nuclear waste. By following the Swedish parliamentary decision these operators have found a joint associate company named SKB (Svensk Kärnbränslehantering $\mathrm{AB}$ equal to Swedish Nuclear Fuel and Waste Management Company) in 1972. Their responsibility is also about transporting nuclear waste and interim storage. Traditionally there is a long-standing association between the management of spent nuclear fuel in Sweden and the industry-led SKB research, development and demonstration project [5]. For the reason of the success of the KBS (kärnbränslesäkerhet, in English: nuclear fuel safety) project it led to a government affirmation to obsess the KBS concept. The introduction of a new legislation, the Nuclear Power Stipulation Act, has been adopted in February 1977 putting pressure on the reactor owners. The Act assessed that they must show exactly how and where spent fuel can be disposed in an absolute safety manner. It was linked to the permission that can be granted to fuel any other reactor [7]. An important change was made when the Stipulation Act (Villkorslagen) has been replaced by the Act on Nuclear Activities in 1984. In addition, the wording "absolute" safety was transferred to the reconfirmation that reactor owners were to be held responsible for a "comprehensive research and development programme" guaranteeing the safe handling, interim storage and domestic geological disposal [6].

Nearly 30 years the whole process is focussed to a stepwise implementation of the multi-barrier KBS-3 concept for final disposal of nuclear fuel.
The Swedish society has high trust in the nuclear industry because it appears to the public that Swedish nuclear power plants operators have a solution to the nuclear waste disposal problem [6]. In 1977, SKB has installed one of the first major international projects on nuclear waste disposal in underground laboratories at former mine Stripa (Bergsladen, located north of Mälaren Lake in northern Svealand). These research activities ended in 1992.

Already in 1983 the SKB has published a report named "KBS-3" as a concept of encapsulation of the spent fuel inside of a natural rock formation. Furthermore, it is protected by additional engineering barriers like Bentonite rings.

In the 1990s the laboratory for reposition technology has moved to Oskarshamn at a depth of 460 meters - research work has been set up from 1990 to 1995 . For the final disposal site finding the SKB has promised to operate a process between 5 and 10 studies in various municipalities, when the first feasibility study has started in 1992. Firstly, all 286 municipalities have been invited, while the result has ended in two positive responses. After that SKB has decided to approach the five municipalities already hosting nuclear facilities [7]. In the period from 1993 to 2000 the SKB has made eight feasibility studies. The two local sites Storuman und Malå (both with no practical experience with nuclear technology) withdrawal in this process was caused by negative municipal referendums. Five out of six local sites - Östhammar, Nyköping, Tierp, Oskarshamn, Hultsfred and Älvkarleby - seemed to be appropriate for a final disposal site. Due to the Swedish Environmental Code, a comprehensive environmental legislation introduced in 1999 has required an Environmental Impact Assessment process, 20 years after the KBS project was initiated [6]. 
Table 1. Timeline of the Swedish Nuclear Waste Management Process [5]

\begin{tabular}{|c|c|}
\hline Year & Issue \\
\hline 1976 & Launch of the KBS nuclear fuel safety project \\
\hline 1984 & $\begin{array}{l}\text { Approval of the industry report about KBS-3 as a basis for the research, } \\
\text { development and demonstration programme; reporting on every third year }\end{array}$ \\
\hline 1990s & $\begin{array}{l}\text { The Svensk Kärnbränslehantering } \mathrm{AB}(\mathrm{SKB}) \text { conducts geological surveys on } \\
\text { regional and local levels in order to select a site for the repository }\end{array}$ \\
\hline 2002 & $\begin{array}{l}\text { SKB begins site investigations for a repository at two potential sites: } \\
\text { in Forsmark (Östhammar Municipality) and in Simpevarp-Laxemar (Oskarshamn Municipality) }\end{array}$ \\
\hline 2007 & Site investigations are finished \\
\hline 2009 & $\begin{array}{l}\text { SKB selects Forsmark for the repository. The Swedish Government will nevertheless make } \\
\text { the final decision on whether the repository will be constructed on the chosen site }\end{array}$ \\
\hline 2011 & $\begin{array}{l}\text { SKB planning to submit a licence application for } \\
\text { construction of the repository in Forsmark }\end{array}$ \\
\hline
\end{tabular}

With regard to sites the SKB has attracted Östhammar (close to Forsmark), Oskarshamn and Tierp as shortlisted. While Tierp has rejected and resigned, the two municipal councils of Östhammar and Oskarhamn have resolved to allow exploration drillings, which began in 2002 [5]. In June 2009, SKB has opted for the location Forsmark. For this reason the Oskarshamn municipality has received a financial compensation. For long-term development projects in the municipality SKB will invest 1.5 billion Swedish kronor (equal to approximately 175 million Euros). According to SKB's view the planning permission for the repository ought to be available in 2015 and the site is to be ready in 2025 [8]. In March 2011, the SKB has submitted an application to the Swedish Radiation Safety Authority to accredit the construction of a repository in Forsmark.

At least, the KBS-3 concept still represents a suitable way how to deal with high-level nuclear waste. The counterpart is that the concept has remained incomplete as long as a local site for final disposal has been undetermined. The Swedish nuclear waste management programme has a positive reputation because of the fluidity, heterogeneity and multiple nature of the KBS-3 concept. The question is if the KBS Programme has delivered for more than 30 years a practical solution to the Swedish nuclear waste problem or has the KBS Programme just achieved what it initially set out to do; as a main goal with regard to nuclear waste management that has transferred to a concept that demonstrates safety. The KBS Programme has always been more concerned with the production of hard and fast signs of the safe disposability of nuclear waste, rather than with actual disposal itself [9, p. 247]. The dominant term was an industrial demonstration of nuclear fuel safety. Furthermore, it can be seen as mediation through demonstration [10, p. 198-199] in contrast to the concept of mediation through dialogue. Nevertheless, the Swedish paradigm how to find a national solution to nuclear fuel safety has been brought at international level by the reason of recent internationalisation of the Swedish nuclear industry [9]. Therefore, the Swedish underground disposal concept is highly interesting for other countries all over the world [10].

One interpretation of the KBS Programme is that it has been labelled as "good nuclear governance" and has been established even before the term government was discussed in broader perspective as new forms of "governing without government" [10].

\section{THE SWEDISH KBS-3-METHOD}

According to the KBS-3-method for the final repository for spent nuclear fuel, SKB's proposal is to encapsulate the spent nuclear fuel in copper canisters with cast iron inserts and depositing the canisters at a depth of about 500 metres in the bedrocks (Fig. 3). Therefore, stable mechanical and chemical conditions are needed. Impermeable copper canisters are embedded in bentonite clay. Additionally, SKB points out that the clay constitutes a buffer against minor rock movements and prevents corrosive substances from getting into the canister. An effective absorption of radionuclides is in place if the canister is damaged [11].

The idea of the Swedish final repository for spent nuclear fuel is based on the principle of multibarriers. Three barriers, the canister, the buffer and the rock, are the repository's barriers (Fig. 4). In sum, this structure shall prevent radioactive substances from reaching the ground level and harming man and the environment. According to SSM (Swedish Radiation Safety Authority) regulations (SSMFS 2008:21) the safety assessment has to cover a period for at least 100,000 years after the closure of the repository to contain nuclear waste safe. For this duration the barriers function has to be in place [12].

Regarding the quantitative risk analysis for the first 100,000 years the General Guidance states the following: "Supplementary indicators of the repository's protective capability, such as barrier functions, radionuclide fluxes 


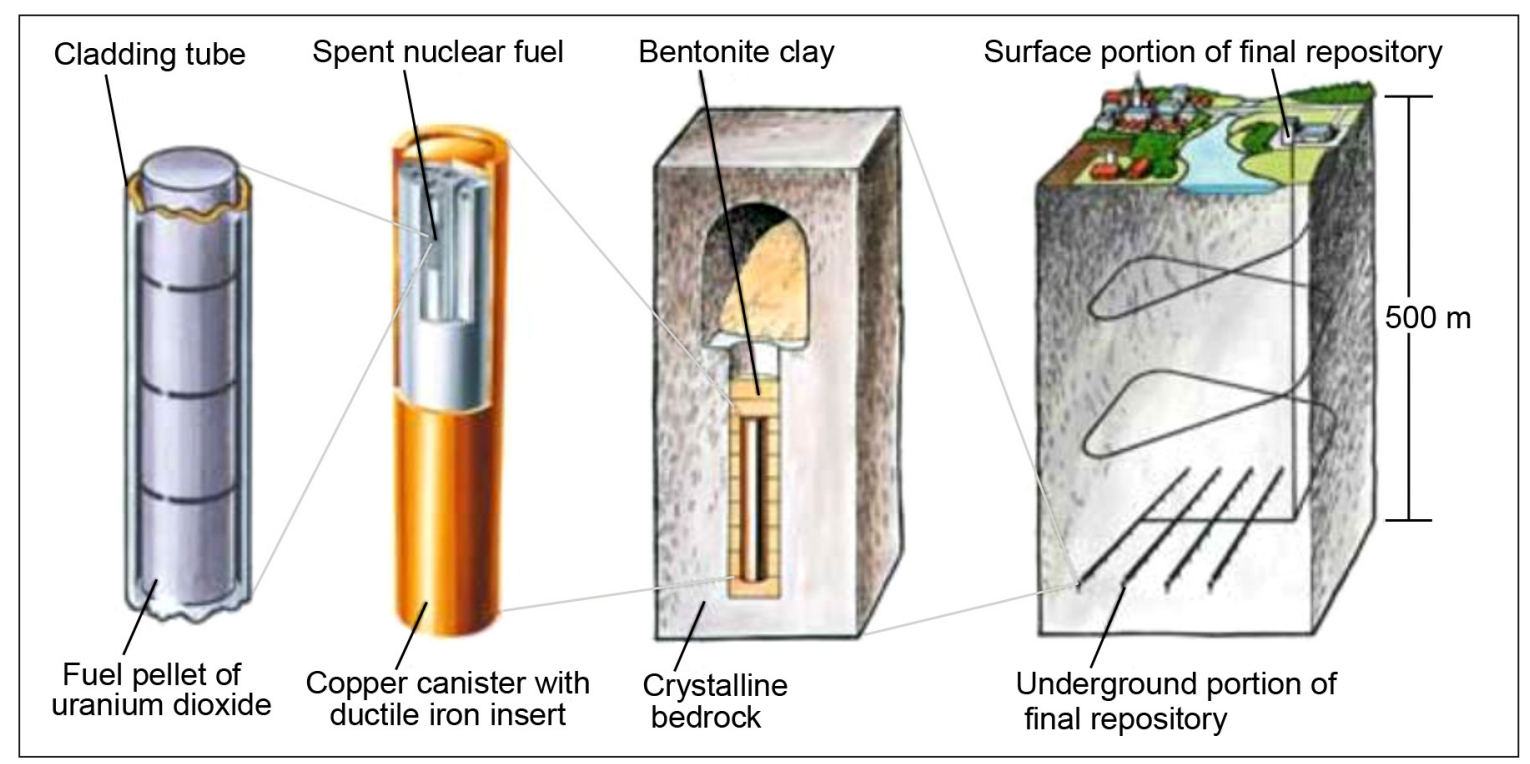

Fig. 3. SKB's method of final disposal [11]

and concentrations in the environment, should be used to strengthen the confidence in the calculated risks."

In Sweden the copper canister plays an important role in the design of the repository. Therefore, long-term physical and chemical stability of copper in aqueous environments is required when the safety evolution in a disposal concept is guaranteed. The corrosion resistance of copper is put into question caused by results under anoxic conditions in an aqueous solution. The conflict is about the verification of safety of copper in comparison with final disposal while public and political concerns were verbalized. On 16 November 2009, the Swedish National
Council for Nuclear Waste has organized a workshop to discuss questions on the issue of "Mechanisms of Copper Corrosion in Aqueous Environments". The workshop has addressed the fundamental understanding of the corrosion characteristics of copper with regard to oxygen-free environments. There is limited information available about the corrosion mechanism and its implication on the containment of spent nuclear fuel in a copper canister and on the question of copper corrosion reaction in pure water as well [13]. The seminar report contents presentations and discussions at the workshop as well as written statements by expert panel members are included. The

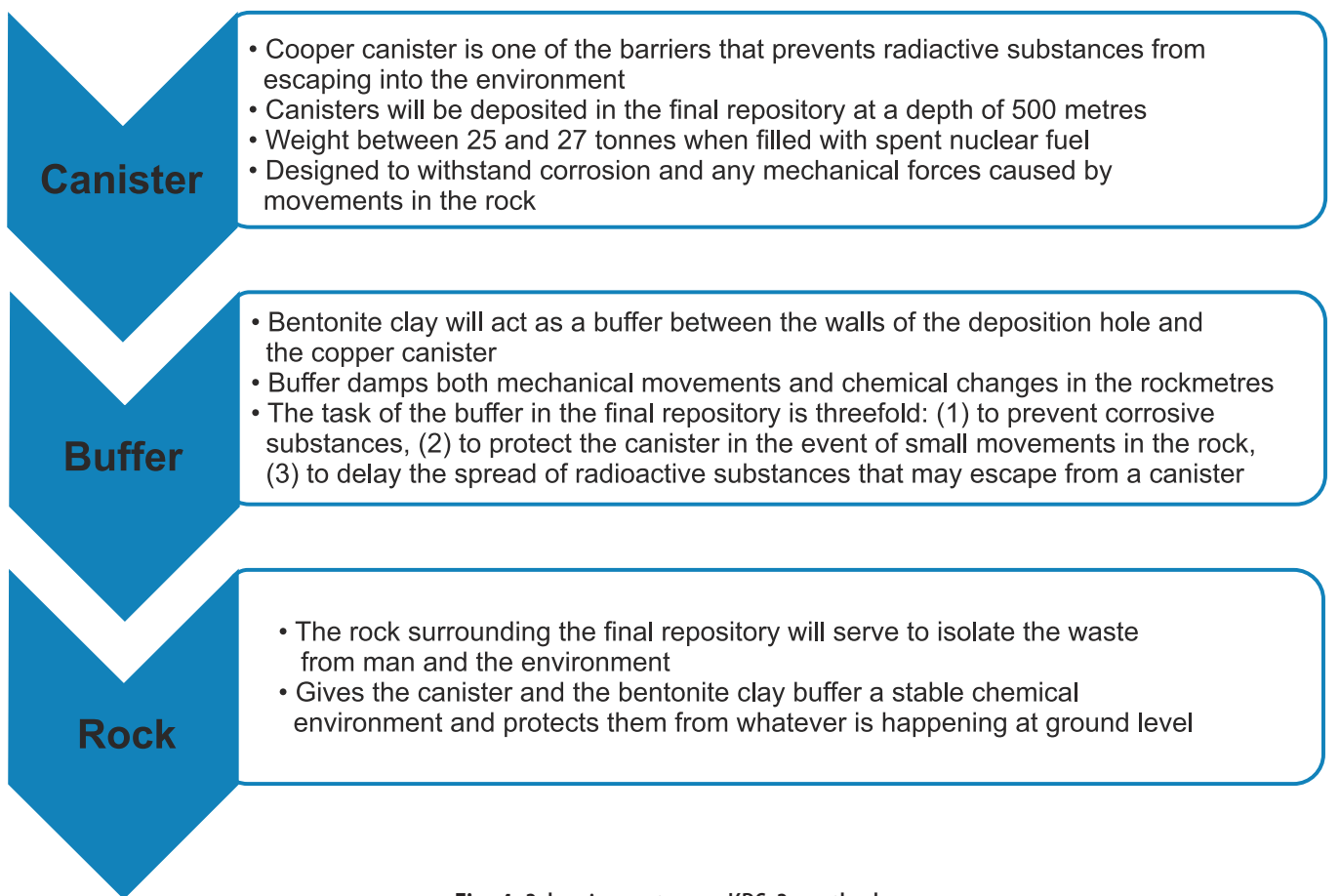

Fig. 4. 3-barrier-system or KBS-3-method 
following passage reflects the current status about KBS3-concept.

The geological environment surrounding the copper canisters will be nearly oxygen-free, and one of the premises on which the KBS-3 rests is the assumption that copper cannot corrode in such an environment. The scientific findings of a small group of researchers at KTH (the Royal Institute of Technology) in Stockholm have therefore been met with widespread interest and debate. Their findings are that copper actually can corrode in pure water, free from oxygen as well as from complexing ions. Since the release of the KTH findings, the long-term safety of the KBS-3 method has been questioned. The deflection is that more research with regard to copper reactions is needed [13].

On 14 June 2013, the sixteenth meeting of the nuclear power industry companies SKB's reference group on research on copper corrosion in an oxygen environment has taken place. In autumn 2012, the MKG (Miljöorganisationernas kärnavfallsgranskning equal to the Swedish NGO Office for Nuclear Waste Review) left the group for the reason they did not get visibility into all the copper corrosion research the association demanded to be published as part of the additions of the final application in the ongoing environmental assessment. To date, the previous findings from 2009 have not been refuted. New results may be published in autumn 2013 [14].

\section{SWEDISH LEGAL AND REGULATORY FRAMEWORK}

The main regulatory body responsible for the supervision of nuclear waste safety and radiation protection is the Swedish Radiation Safety Authority (SSM). On 1 July 2008, the
Swedish Nuclear Power Inspectorate (SKI) and the Swedish Radiation Protection Institute (SSI) were merged to form the joint authority SSM.

The responsible agency for radioactive waste management is the Ministry of the Environment. An independent committee, named Swedish National Council for Nuclear Waste that has been established in 1985, is attached to the Ministry. The Swedish National Council for Nuclear Waste was previously known as KASAM.

In reference to the Swedish law the polluter-pays principle is applied. The owner of a nuclear power plant has the full responsibility for the safe handling and final disposal of spent nuclear fuel and nuclear waste that is produced. The financial aspects are included into the nuclear waste management for the reason economical boundary conditions are an important element in the debate. In 1972, the Swedish nuclear power plants owners have established the Swedish Nuclear Fuel and Waste Management Company (SKB).

The SKB is prompted by law to present a nuclear waste handling or rather disposal solution. For the whole process the authorities will review it, based on these results they make their recommendation to the government. The government will establish a double structure to receive two proposals. One actor is the Environmental Court which comes up with provisions with regard to the Environmental Code (1998:808), respectively Environmental Code (Ds 2000:61).

The other player is the SSM who will stipulate conditions under the Acts on Nuclear Activities (1984:3) and on Radiation Protection (1988:220). Beyond that the SSM acts as a consultative body to the Environmental Court.

In sum, responsibility in the nuclear waste management is divided. The Swedish Nuclear Fuel and Waste Manage-

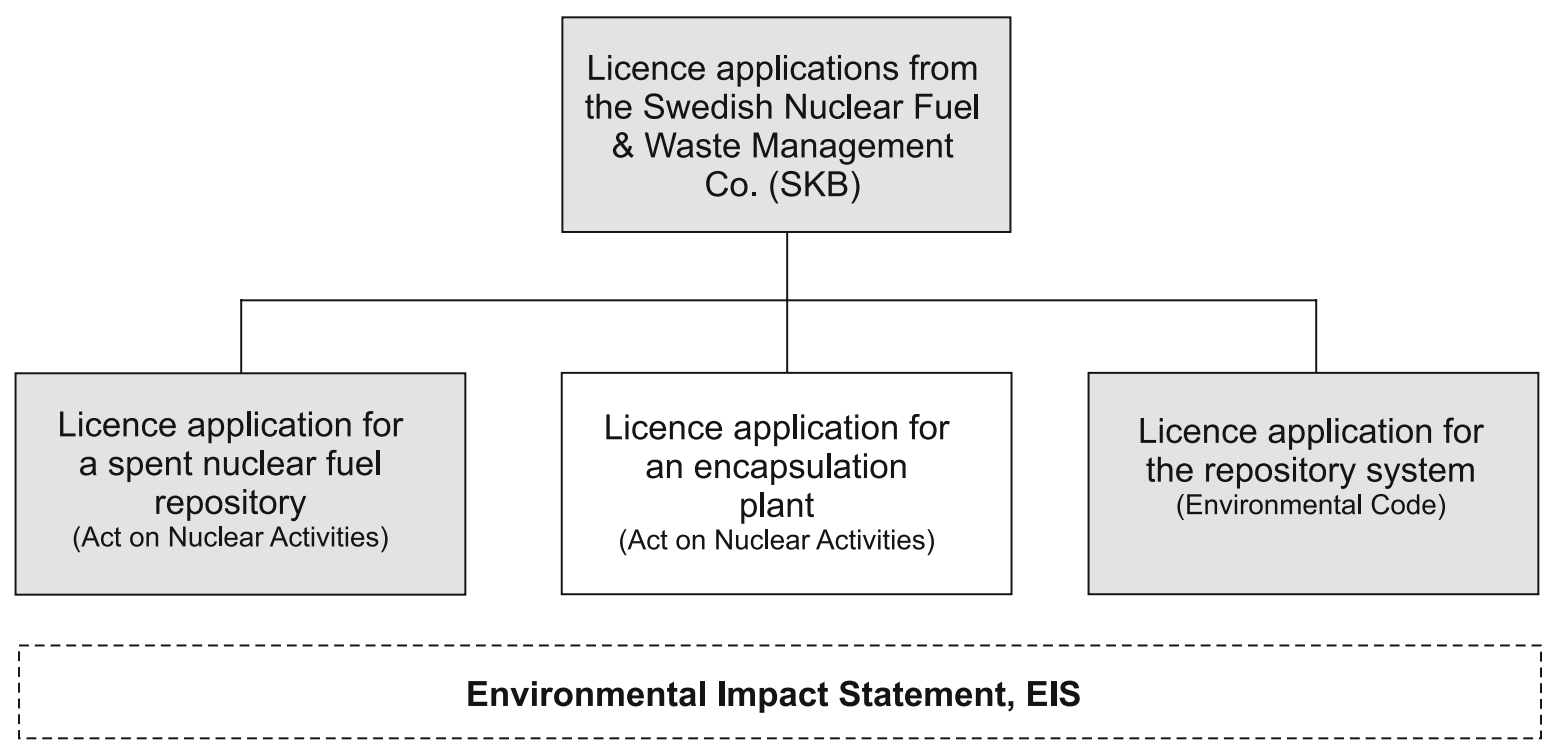

Fig. 5. The licence applications [15] 
Table 2. Overview about some legal aspects of Swedish nuclear waste management (own illustration [16, p. 77; 17])

\begin{tabular}{|c|c|c|}
\hline Main acts & Ordinances & $\begin{array}{c}\text { Regulations for transport and } \\
\text { final disposal of spent fuel }\end{array}$ \\
\hline $\begin{array}{l}\text { Nuclear Liability Act (1968:45) implements } \\
\text { Sweden's obligations as a party to the } 1960 \\
\text { Paris Convention on Third Party Liability in } \\
\text { the Field of Nuclear Energy and the } 1963 \\
\text { Brussels Convention Supplementary } \\
\text { to the Paris Convention. }\end{array}$ & & Safety in Nuclear Facilities - (SSMFS 2008:1) \\
\hline $\begin{array}{l}\text { Nuclear Power Stipulation Act (1977:140) concerns } \\
\text { the priority to fueling a nuclear power plant and } \\
\text { its owner had to show how and where the SNF } \\
\text { could be finally stored with absolute safety. }\end{array}$ & & $\begin{array}{l}\text { Planning before and during } \\
\text { Decommissioning of Nuclear Facilities } \\
\text { (SSMFS 2008:19) }\end{array}$ \\
\hline $\begin{array}{l}\text { Nuclear Activities Act (1984:3) concerns } \\
\text { mainly security and control issues and } \\
\text { the overall safety of nuclear operations. }\end{array}$ & $\begin{array}{l}\text { Nuclear Activities } \\
\text { Ordinance } \\
(1984: 14)\end{array}$ & $\begin{array}{c}\text { The Swedish Radiation Safety } \\
\text { Authority's General Recommendations } \\
\text { concerning Section } 5 \text { of the Nuclear } \\
\text { Activities Act (1984:3) }\end{array}$ \\
\hline $\begin{array}{l}\text { Radiation Protection Act (1988:220) aims } \\
\text { to protect people, animals and the environment } \\
\text { from the harmful effects of radiation. }\end{array}$ & $\begin{array}{l}\text { Radiation Protection } \\
\text { Ordinance } \\
(1988: 293)\end{array}$ & $\begin{array}{l}\text { Safety in connection with the disposal } \\
\text { of nuclear material and nuclear waste } \\
\text { (SSMFS 2008:21) }\end{array}$ \\
\hline $\begin{array}{l}\text { Environment Code (1998:808) addresses } \\
\text { environmental aspects of nuclear activities, } \\
\text { and lists "nuclear activities" among several other } \\
\text { "environmentally hazardous activities". }\end{array}$ & & $\begin{array}{l}\text { Protection of Human Health and the } \\
\text { Environment in Connection with the Final } \\
\text { Management of Spent Nuclear Fuel and } \\
\text { Nuclear Waste (SSMFS 2008:37) }\end{array}$ \\
\hline $\begin{array}{l}\text { Environmental Code (Ds 2000:61) update } \\
\text { of former EC, some amendments have been } \\
\text { made and entered into force } \\
\text { up to } 1 \text { August } 2000 \text {. }\end{array}$ & & $\begin{array}{l}\text { Discharging of Goods and Oil from Controlled } \\
\text { Areas at Nuclear Facilities (SSMFS 2008:39) }\end{array}$ \\
\hline \multirow[t]{2}{*}{$\begin{array}{l}\text { Dangerous Goods Act (2006:263) constitute } \\
\text { the basis and conditions for the transport } \\
\text { of dangerous goods. }\end{array}$} & $\begin{array}{l}\text { Transport of } \\
\text { Dangerous Goods } \\
\text { Ordinance } \\
\text { (SFS 2006:311 }\end{array}$ & $\begin{array}{l}\text { Regulations concerning basic provisions for } \\
\text { the protection of workers and the general } \\
\text { public in practices involving ionising } \\
\text { radiation (SSMFS 2008:51) }\end{array}$ \\
\hline & & $\begin{array}{l}\text { Regulations and general advice concerning } \\
\text { clearance of materials, rooms, buildings } \\
\text { and land in practices involving ionising } \\
\text { radiation (SSMFS 2011:2) }\end{array}$ \\
\hline $\begin{array}{l}\text { Financing of Management of Residual } \\
\text { Products from Nuclear Activities Act } \\
\text { (2006:647) contains provisions for } \\
\text { the future costs of spent fuel and nuclear } \\
\text { waste disposal, decommissioning of reactors } \\
\text { and other nuclear installations and } \\
\text { research in the field of nuclear waste. }\end{array}$ & $\begin{array}{l}\text { Instructions for } \\
\text { the Swedish } \\
\text { Radiation Safety } \\
\text { Authority Ordinance } \\
\quad(2008: 452)\end{array}$ & \\
\hline
\end{tabular}

ment Company acts as an implementer, regulator function is fulfilled by the Swedish Radiation Safety Authority, its responsibility is for the supervision of nuclear waste safety and radiation-protection. SSM's regulation and guidance on post-closure repository safety has two parts: radiation protection and safety regulation.

The Swedish Radiation Safety Authority is regularly reviewing cost calculations by nuclear industry. The government is responsible for the determinate level of fees NPP units/per production to pay to the Nuclear Waste Fund. The government also sets the guarantees.
The administration and management to collect the fee lie at the Swedish Nuclear Waste Fund, whereas the Swedish National Debt Office administers and manages guarantees.

Another important agency with responsibility is the Swedish National Council for Nuclear Waste. The regulations SSMFS 2008:37 contain the requirements:

- Protection of human health.

- General environmental protection goals.

- Application of optimization.

- Best Available Technique (BAT). 


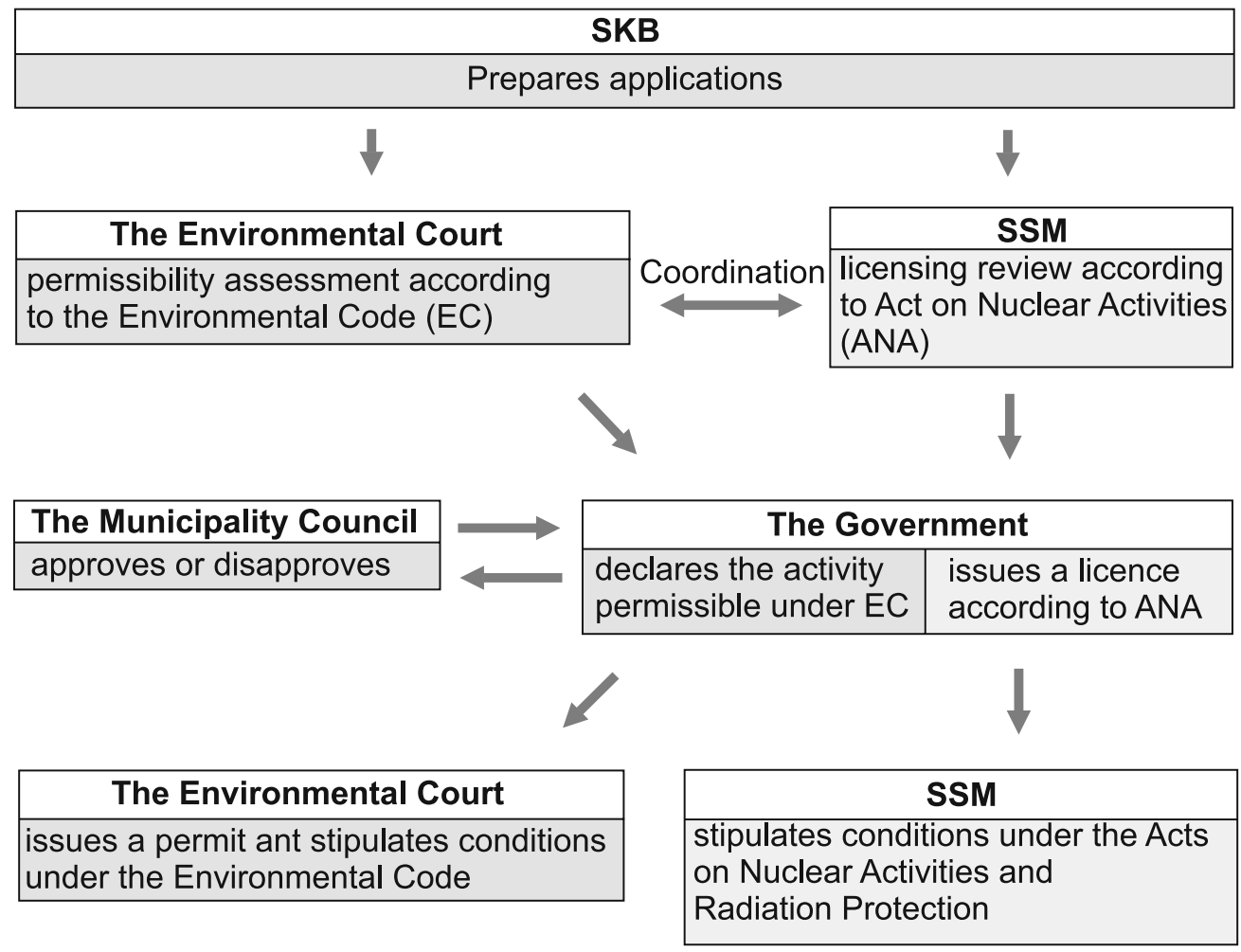

Fig. 6. The licensing review procedure [17]

The relevant guidance advises on the reporting of risk, BAT and optimization for different time periods after closure, selection of scenarios, calculation of risk, handling of uncertainty and risk mitigation [18]. According to regulations of safety requirements on the design of the repository, barrier functions and safety reporting as well as regulations to the construction and operational phases of the repository are included.

In Fig. 7 the whole process for licensing under the Environmental Code and the Nuclear Activities Act of a final repository for spent nuclear fuel is diagrammed.

\section{FINANCIAL ISSUES ON NUCLEAR WASTE MANAGEMENT}

The financing system has been reorganized in 1996 when the Nuclear Waste Fund (NWF) - a government authority - was established to hold the funded assets. The NWF has its own Board of Governors but no working staff, on behalf of them the Financial and Administrative Services Agency controls administrative and capital management of the Board. Originally the system was invented by the Swedish Parliament in 1982, the holder of a licence to own or operate a nuclear power plant (NPP) pays a special fee to the state to compensate the costs for safe future management, disposal of the spent nuclear fuel and decommissioning and dismantling of NPP. The fee is determined at a given rate per kWh of electricity produced by NPP. The Act 1992:1537 on the Financing of Future Expenses on Spent Nuclear Fuel has been replaced by the Act (2006:647) on Financing of Management of Residual Products from Nuclear Activities. Therefore, since 1 January 2008, the fee system defines an amount in kronor, to be paid by a fee liable licensee who no longer delivers nuclear energy. The new financial system comprises coordination between the periodic review of cost calculations and the periodic review of the R \& D programme - one important element is the regulatory review of cost calculations that will be taken every three years. The Swedish Radiation Safety Authority and the government have to decide on the size of the fee. The SSM together with the government, only for certain cases, approve the pay-off from the NWF [18]. In general, the licensees must provide guarantees for the costs the fee should cover. To this scope guarantees are for saving reserves to secure future financial resources.

Whether the NWF is working inadequately, the guarantees ought to be covering all costs. The duty to pay the nuclear waste fee and assure guarantees comes to an end when the licensee has completed its obligations, especially with regard to the nuclear activities act or deliverance made by law.

On 5 June 2013, the SSM has published a press release "New proposal provides a more robust funding system - Nytt forslag ger ett mer robust finansieringssytem". By order of the government the SSM has reviewed the 


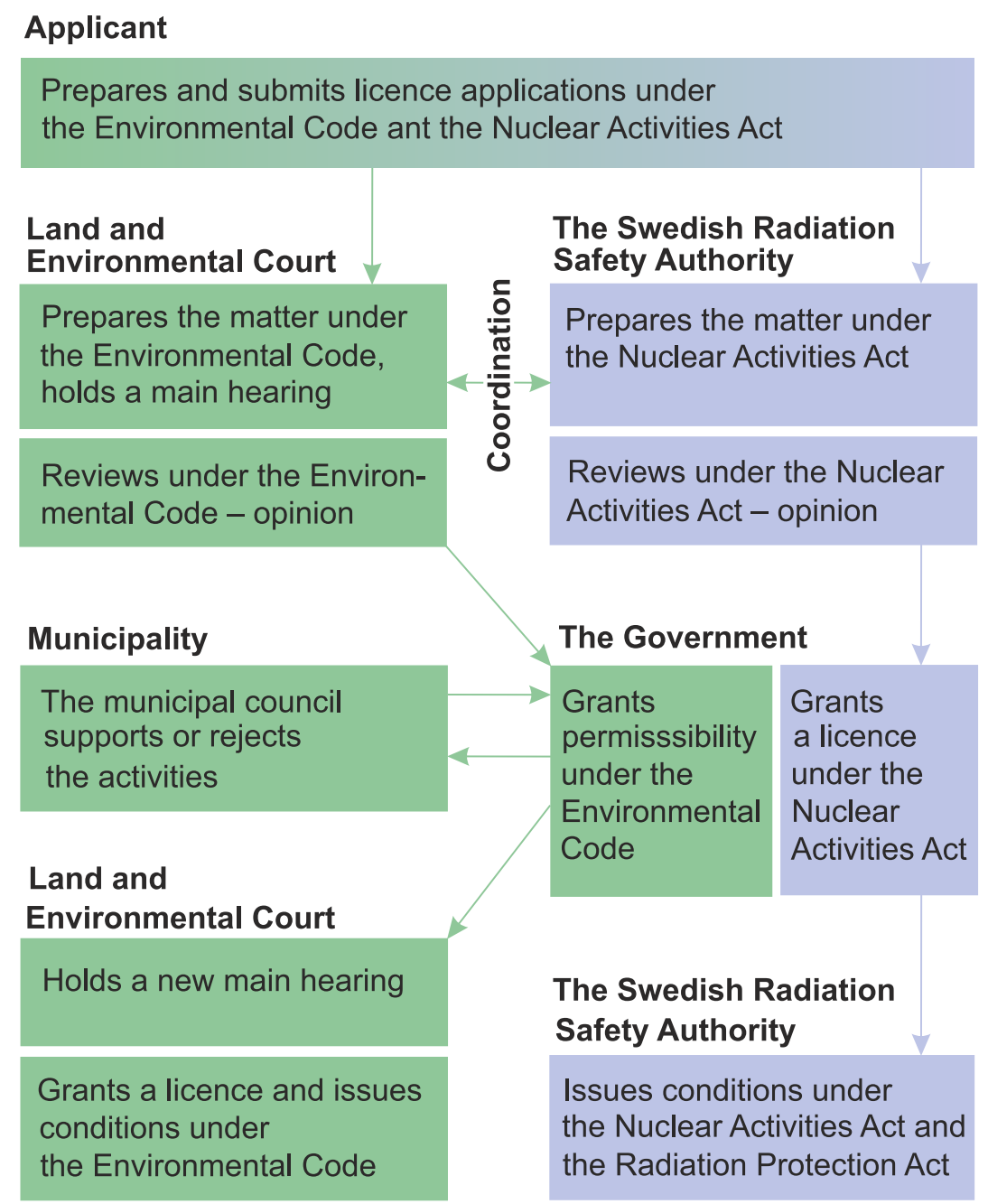

\section{Applicant}

Initiates planning on the part of the municipality

\section{Municipality}

Prepares a detailed development plan under the Planning and Building Act

\section{Municipality}

The municipal council adopts the detailed development plan

\section{Applicant}

Applies for a building permit

\section{Municipality}

Grants a building permit

Fig. 7. Schema on the process for licensing under the Environmental Code and the Nuclear Activities Act of a final repository for spent nuclear fuel [19]

Financial Act and financing regulation. The main aim of the authorities was to clarify how the principles of nuclear waste fee were calculated and how the funds in the Nuclear Waste Fund are managed in order to reduce the economic risk. Currently, the SSM has submitted a report to the Ministry of Environment and gave some recommendations on law and regulation changes linked to NWM $[21,22]$.

Therein different proposals for major changes have been presented [21]:

- Nuclear Waste Fund's investment opportunities broadened to include inter alia a specific shareholding.

- The discount rate curve used to calculate the value of future cash and payments linked to the nuclear waste fund's expected returns.

- Calculation of nuclear waste fees are based on the nuclear power plants in operation for 50 years instead of 40 years as it was calculated before.

It is important to point out that the estimates of fees and guarantees have been made as part of a commission's impact assessment. Therefore this information can only be taken as an indication for future fee calculations. Concurrently, the SSM has officially considered that a fee at the current level, $0.02 \mathrm{SEK} / \mathrm{kWh}$ (historical start point $0.01 \mathrm{SEK} / \mathrm{kWh}$ in 1996) [22], can cover the cost of decommissioning nuclear power plants and disposal of the spent nuclear fuel. Reevaluating of the NWF will be made every three years - integrates costs of dismantling reactors, future productivity and forecasts of electricity production at nuclear power plants.

The Swedish NGO Office for Nuclear Waste Review (MKG) has a contrary information that the initial proposals (by SSM) of the investigation presented in the consultation stage of the investigation pointed to the need for an increase in the nuclear waste fee by 0.02 SEK to about 0.04 SEK per kWh [23]. The Swedish National Debt Office has concluded that "these proposals contain a number of uncertain estimates of various parameters that have a major impact on fees and security amount. They include the assumptions of remaining operating time, and the 


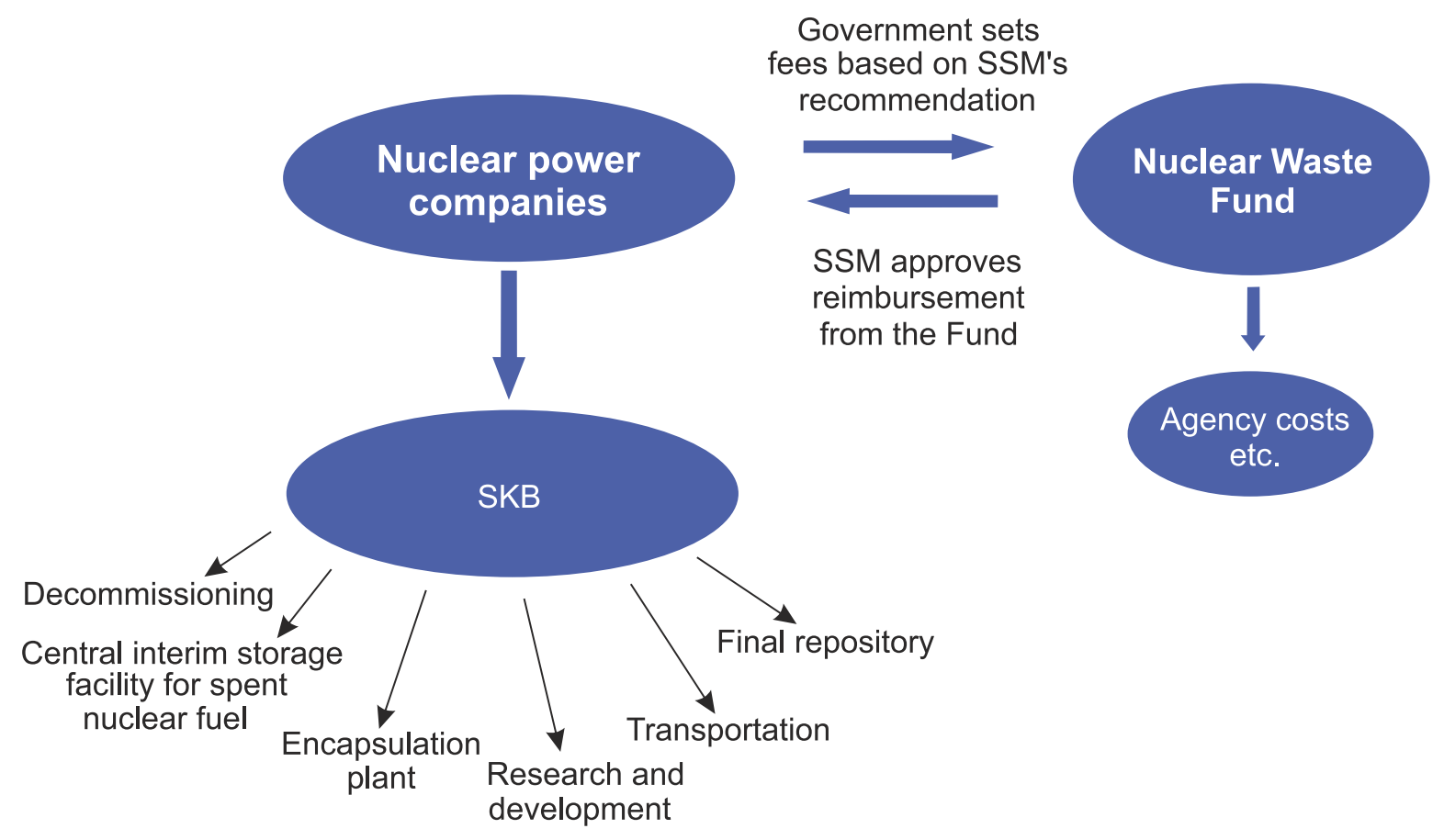

Fig. 8. The financing system for nuclear waste [20]

model for the determination of the discount rate (including specific levels of risk premium) and the exact placement restrictions for different asset classes [23].”

An investigation and decision for the next funding period (2015-2017) with regard to fee rate will be made in autumn 2014 after the Riksdag's election.

\section{THE SWEDISH REVIEW PROCESS}

Due to the implementer function, the Swedish Nuclear Fuel and Waste Management Company has submitted threepart-divided application to deal with nuclear waste [24]:

- An application under the Act on Nuclear Activities for CLAB (an interim storage facility for spent nuclear fuel) and an encapsulation facility in Oskarshamn (1st submission in November 2006, amended in 2009; the application was submitted again completely on 16 March 2011).

- An application under the Act on Nuclear Activities for a spent fuel repository, including the site and method (submitted on 16 March 2011).

- An application under the Swedish Environmental Code covering the entire repository system (CLAB, encapsulation facility and repository; submitted on 16 March 2011).

For the whole review process a period of two years has been applied, when the SSM provides a statement to the government. Afterwards the government will decide to grant a licence to SKB or reject the submitted application. Already in October 2012 the SSM has published their technical report 2012:65 and focuses on the prospect for nuclear criticality safety in the final disposal:

"The objective of the review is to determine the credibility of implementing the conclusions in the application and the appropriateness of the criticality safety procedures. SSM will review the specific, detailed evaluations of various scenarios at a later stage [25, p. 3]."

For the evaluation about terms of criticality safety some general directions were made from SSM.

A summary of the expectations of the initial SSM review is that the quality and completeness of the application shall be evaluated, with the perspective that a detailed SSM safety review can be carried out in the next phase. The SSM has addressed a question related to the criticality safety:

"The scope of the criticality safety review includes the spent fuel in copper canisters and any potential for in-leakage of water or out-leakage of fissile material (uranium and / or plutonium in the used fuel) from the canisters. The review shall evaluate whether the SKB method of burnup credit can be acceptable and whether SKB can apply this method correctly for controlling the subcriticality of all canisters [25, p. 15]."

For the reason of a step-wise review process, the following steps are compromising five elements regarding licensing issues: 
1. To construct, own and operate the facilities.

2. Commencement of the construction phase.

3. Test operation.

4. Regular operation.

5. Decommissioning and / or closure.

On 16 March 2011, SKB has submitted its licence applications to the Authority equated with the first step of the review process. Nevertheless, it is a highly important step caused by the final opportunity for broad public involvement through the Environmental Impact Assessment (EIS) process. The SSM opens a corridor for national consultation whereas special case is a possible municipal veto on the part of the two municipal authorities Oskarshamn and Östhammar: the municipality decides. An area of conflict is about the two forms of nuclear waste management policy in Sweden "demonstration" and "dialogue". One approach could be mediation through demonstration, another one is mediation through dialogue that means the admission contingent on facts while realities are often shown through demonstrations. By following dialogue mediation collective suspensions of judgement and the capability of extended peer review have to be included [9, p. 202]. With reference to a public consultation meeting in Forsmark, 1st June 2006, "Alternative Methods, the Siting Process and Society's Future Ability to Take Care of Spent Nuclear Fuel" [26], a SKB consultant has presented the KBS(-3) repository concept as the justified option compared to a time span where society's development stands foreseeable. Nevertheless, four alternatives - without deeper scrutiny - to KBS were offered [9]:

1. Zero-alternative $>$ waste continues to be deposited in the central interim storage.

2. Surveilled dry deposit.

3. Deep boreholes.

4. Transmutation.

The "first step" has an enormous significance as several important decisions are to be taken, e. g. selection of the method and site. There are difficulties because SKB's

Table 3. Plan for a running process of review (own illustration)

\begin{tabular}{|c|c|}
\hline Date & Issue \\
\hline 27 May 2011 & $\begin{array}{l}\text { Swedish Radiation Safety Authority begins its technical review; two phases: } \\
\text { (1) initial technical review phase, (2) main review phase. } \\
\text { 1st phase involves a broad review of the application documents } \\
\text { in order to determine whether the licence applications are sufficiently } \\
\text { complete and of sufficient quality to enter } \\
\text { the extensive main review phase. }\end{array}$ \\
\hline $\begin{array}{l}\text { November } 2012 \\
\text { Phase 1a }\end{array}$ & $\begin{array}{l}\text { The initial technical review phase is anticipated } \\
\text { to formally continue until November } 2012 .\end{array}$ \\
\hline $\begin{array}{l}\text { November } 2012 \\
\text { Phase } 1 \mathrm{~b}\end{array}$ & $\begin{array}{l}\text { When the initial acceptance review was completed, the application } \\
\text { documents were referred to other bodies for consideration and comments. } \\
\text { Over the years the Swedish Radiation Safety Authority has maintained } \\
\text { dialogue with the external actors monitoring SKB's work and who have also } \\
\text { been interested in the Authority's role in the process. Some of these stakeholders } \\
\text { have received funding from the Nuclear Waste Fund for work in this area and } \\
\text { have built up their own expertise in the field. The Authority wishes to use } \\
\text { this interest and expertise in the area as a platform for requesting the views } \\
\text { of national stakeholders on the entire application documents. The consultation } \\
\text { (interest and expertise shall be used as a platform to request the view of } \\
\text { national stakeholders) responses are to have been received by } \\
\text { the Swedish Radiation Safety Authority by } 1 \text { June } 2012 \text {. }\end{array}$ \\
\hline March 2013 & $\begin{array}{l}\text { Reply of SKB on the remittance comments } \\
\text { or a supplement of the application. }\end{array}$ \\
\hline March-August 2013 & $\begin{array}{l}\text { The Environmental Court requests any supplementary information, } \\
\text { possibly sessions in the supplementation phase. }\end{array}$ \\
\hline August-October 2013 & Submission of any supplementary information will be demanded from SKB. \\
\hline & $\begin{array}{l}\text { Application is published for public comment } \\
\text { with regard to the Environmental Code. }\end{array}$ \\
\hline January 2014 & $\begin{array}{l}\text { Statements received from government authorities, } \\
\text { organizations and parties are sent to SKB for answering. }\end{array}$ \\
\hline January-August 2014 & Continued written exchange. \\
\hline August-September 2014 & Main hearing. \\
\hline January-March 2015 & Continued processing and statement. \\
\hline
\end{tabular}


application was not able to offer all details in terms of construction and operation. Nevertheless, the SKB has to demonstrate its competence to construct and run the facility in fulfilling the compulsory requirements and that the facility can be constructed in an appropriate way: sufficient level of safety and security after the repository has been closed in the future. In particular, the first step contains a strong focus on key assumptions in the analysis of longterm safety. International agencies like the International Atomic Energy Agency (IAEA) have to be involved while it is in compliance with international practice. By designing, constructing and commissioning a nuclear facility such as repository long-term processes have to take place in steps. The Authority (here:SSM) will have an expert circle to review SKB's proposal with regard to construction engineering, plant technology, geology, hydrology, chemistry, materials chemistry, materials engineering, social sciences, technical physics and radioecology. Parallel reviewing will be made by the Environmental Court considering the application under the Swedish Environmental Court.

Currently, at a meeting between the SSM and SKB on 12 November 2013 SSM's opinion has been discussed, while SSM has emphasized the need to have more information and answers to all the questions that were set but have not been delivered yet [27]. As argued by SKB, complemental information and answers will be sent to SSM on 20 December 2013, some background reports will be sent in January 2014. The next comprehensive reconciliation meeting will be on 4 February 2014 [28].

\section{CONCLUDING REMARKS}

The problem of Nuclear Waste Management has similarities all over the world. To get rid of nuclear waste depends on countries' respective histories, technology preferences, political cultures and institutional settings. In general, countries have different goals and, hence, processes.

To evaluate the article results, it is useful to resort to some elements in Chapter 2 "Research Implementation" (p. 2-3): (1) coherent objectives are existing, (2) incorporation of a useful and causal theory, (3) availability of financial resources, (4) hierarchical integration orientated on institutions, (5) existence of decision-rules of implementing agencies, (6) identification or recruitment of implementing officials and (7) granting formal access by outsiders.

1. Coherent objectives are existing $(+)$

The main goal of the Swedish nuclear waste management concept is to demonstrate safety.

2. Incorporation of a useful and causal theory (-)

In Sweden, a strong connection between nuclear waste management, the licensing of nuclear power plants and the target to achieve the demonstration of a "safe" final storage were fulfilled and presented within the KBS-3 me- thod. From the beginning SKB research was more focussed on engineered barriers and on the option or concept of geological disposal without fetching back. The basic strategy has been to demonstrate safe disposal as a question of engineered barriers to prove a principle solution. In 2009 , some natural scientists have cast doubt on the KBS3 method because of copper canister corrosion. A current technical note by 2012 from SSM points out some questions, needed to be answered by SKB for continuing the process of nuclear waste management, especially in reference to some SKB reports, a current one is SKB R-13-31 "Copper Corrosion in Ultra Pure Water". Another remark is the question about practical stability, it means that the KBS-3 programme was not consistent over time, has resulted in fluidity, and still has not proved as an appropriate method.

3. Availability of financial resources (?)

A lot of different information circulates about financial aspects of NWM. By referring to the source from MKG the Swedish Radiation Safety Authority (SSM) would raise NWF fee to $0.04 \mathrm{SEK} / \mathrm{kWh}$ - initial proposals of the investigation presented in the consultation stage of the investigation - which means a doubling compared to the currently adopted $0.02 \mathrm{SEK} / \mathrm{kWh}$. One can notice that the former $0.01 \mathrm{SEK} / \mathrm{kWh}$ had not been enough to cover all costs. In general, it is difficult to calculate such costs. The storage / disposal is expected for more than 100,000 years, high uncertainty is given.

4. Hierarchical integration orientated on institutions (+)

For Sweden there is a close cooperation between the state and the nuclear industry, significant as a result of a strong policy network which was established and persists. Therefore it is a structure of inclusion from state and economy but of exclusion from civil society and environmental organizations. Since the beginning of Swedish NWM process in the 1970s the responsibility is characterized by a delegation to the nuclear power plant owners themselves. The distance from political institutions decision-making about the issue radioactive waste is a tacit acceptance.

5. Existence of decision-rules of implementing agencies (o)

The process how to legitimise the whole process, make pre-investigations, the selection of the site Forsmark has delivered some questions. A site selection process was presented as a voluntary action of some municipals. Voluntarism is perhaps helpful for the selection process which additional inspections are necessary and the result was not communicated in an appropriate manner. It is the style of the importance of non-politicizing the issue about a repository - only questions about final disposal: technical and local. To find out the best possible site is maybe not ensured when only voluntarism is taking place. One has to think about the fact that a postulate site will not fulfil the 
final disposal concept requirements. Then another solution is needed. The function of a municipality is crossing three spheres: civil society, state and economy.

6 . Identification or recruitment of implementing official (+)

It seems to be clear with regard to a quote from SKB's website: "SKB, Swedish Nuclear Fuel and Waste Management Company, is tasked with managing Swedish nuclear and radioactive waste in a safe way. In 2009 we selected a site for the Spent Fuel Repository and now we have submitted the applications to build the repository in Forsmark." Also different ministries are involved. The question of checks and balances is not intended in identification or recruitment of implementing officials.

7. Granting formal access by outsiders (-)

Civil society is often tardy involved, a large amount of nuclear waste has been already produced, often policy is yet formulated and only the implementation remains. Therefore, the coordination of policy together with parallel policy implementation is a huge restraint to achieve a solution with regard to nuclear waste regulation. To quote an example, MKG did not get visibility into all the copper corrosion research association demanded to be published as part of the additions of the final application in the ongoing environmental assessment. This dealing with the research results on copper corrosion in an oxygen environment counts negative in the estimation.

At the moment a long-term solution for nuclear waste in Sweden is still under question. The Swedish model is widespread and a further outcome is that the nuclear industry has a highly control over nuclear waste management and therefore autonomous influence. With regard to learning processes it is necessary to re-integrate process and to regard checks and balances as a permanent task in nuclear waste management. Also technical issues, i. e. copper reactions, are highly debated again with a predetermined outcome. It is unclear what does it mean for the time horizon of the Swedish final disposal concept - from implementing programme in 2015 the approval / licence should be granted and the plan is to have the repository operational in 2025. Further research with regard to the Swedish nuclear waste management case is highly demanded.

Received 1 June 2013 Accepted 3 March 2014

\section{References}

1. Palmu M., Eng T., Beattie T. M. Towards an 'implementing geological disposal technology platform' in Europe. Mineralogical Magazine. 2012. Vol. 76(8). P. 3439-3444.
2. Lidskog R., Sundqvist G. On the right track? Technology, Geology and Society in Swedish nuclear waste management. Journal of Risk Research. March 2004. Vol. 7(2). P. 251-268 (18).

3. Flüeler T., Stauffacher M., Krütli P., Moser C., Scholz R. W. Cross-cultural space of radioactive waste governance in a globalizing world. Proceedings of the Conference on Managing Radioactive Waste Problems and Challenges in a Globalizing World, Gothenburg, 15-17 December 2009. http://e-collection.library.ethz. ch/eserv/eth:1633/eth-1633-01.pdf

4. Sabatier P. A., Mazmanian D. The Implementation of Public Policy: A Framework of Analysis. Policy Studies Journal. 1980. No. 8. P. 538-560.

5. Swedish Radiation Safety Authority. We won't say 'yes' until the safety issue has been solved. Last updated 2011-3-19. http://www.stralsakerhetsmyndigheten.se/ In-English/About-the-Swedish-Radiation-SafetyAuthority1/The-site-for-a-spent-nuclear-fuel-repo sitory1/News/We-wont-say-yes-until-the-safety-issuehas-been-solved/

6. Elam M., Sundqvist G. Meddling in Swedish success in nuclear waste managements. Environmental Politics. 2011. Vol. 20(2). P. 246-263.

7. Sundqvist G. The Bedrock of Opinion. Science, Technology and Society in the Siting of High-Level Nuclear Waste (Environment \& Policy). Volume 321. 2002.

8. Berner B., Drottz Sjöberg B. M., Holm E. Social Science Research 2004-2010. Themes, Results and Reflections. SKB, April 2011. http://www.skb.se/upload/publications/ pdf/SocialScienceResearch2004_2010webb.pdf

9. Elam M., Soneryd L., Sundqvist G. Demonstrating safety-validating new build: the enduring template of Swedish nuclear waste management. Journal of Integrative Environmental Sciences. 2010. Vol. 7. No. 3. P. 197-210.

10. Elam M., Sundqvist G. The Swedish KBS Project: A last word in nuclear fuel safety prepares to conquer the world? Journal of Risk Research. 2009. Vol. 12. Issues 7-8. P. 969-988.

11. SKB. Our Method of Final Disposal. http://www.skb.se/ Templates/Standard__24109.aspx

12. Long-term Safety for the Final Repository for Spent Nuclear Fuel at Forsmark. Main Report of the SR-Site Project, Volume I, Technical Report, TR-11-01. Svensk Kärnbränslehantering AB, March 2011.

13. The Swedish National Council for Nuclear Waste. Mechanisms of Copper Corrosion in Aqueous Environments. A Report from the Swedish National Council for Nuclear Waste's Scientific Workshop, Report 2009: 4e. 2009.

14. MKG (the Swedish NGO Office for Nuclear Waste Review). Sextonde mötet för referensgruppen för SKB: 
s kopparkorrosionsforskning. 2013. http://www.mkg. se/sextonde-motet-for-referensgruppen-for-skbskopparkorrosionsforskning

15. OECD. The Post-Closure Radiological Safety Case for a Spent Fuel Repository in Sweden. An International Peer Review of the SKB Llicence-Application Study of March 2011 (Final Report), NEA/RWM/PEER(2012)2. 2012.

16. OECD. Nuclear Legislation in OECD Countries. Regulatory and Institutional Framework for Nuclear Activities. Sweden, 2008. https://www.oecd-nea.org/law/ legislation/sweden.pdf

17. OECD. Radioactive Waste Management Programmes in OECD/NEA Member Countries. Sweden, 2005. P. 1-9 $(2-3)$.

18. Dverstorp B., Wiebert A., Jensen M. New Guidance for Geological Disposal of Nuclear Waste in Sweden. Proceedings of the 11th IHLRWM Conference, 30 April-4 May in Las Vegas, 2006.

19. Swedish National Council for Nuclear Waste. Licensing under the Environmental Code and the Nuclear Activities Act of a Final Repository for Spent Nuclear Fuel. Report 2011:2e, Translation of Report. Stockholm, 2013. P. 1-41 (5).

20. Kärnavfallsfonden. Activity Report 2010. http://www. karnavfallsfonden.se/download/18.2595a92612f8a8 de34880003547/Verksamhetsber\%C3\%A4ttelse+2010+ engelska.pdf

21. Swedish Radiation Safety Authority. Förändringar $i$ lagen (2006:647) om finansiella åtgärder för hanteringen av restprodukter från kärnteknisk verksamhet och förordningen (2008:715) om finansiella åtgärder för hanteringen av restprodukter från kärnteknisk verksamhet, SSM 2011:4690:44. 2013. http://www.mkg.se/ uploads/SSM_Rapport_Forandringar_i_finansierings lagen_och_finansieringsforordningen_130605.pdf

22. Swedish Radiation Safety Authority. Nytt forslag ger ett mer robust finansieringssystem. 2013. http://www. stralsakerhetsmyndigheten.se/Om-myndigheten/Ak tuellt/Nyheter/Nytt-forslag-ger-ett-mer-robust-finan sieringssystem-/

23. MKG (the Swedish NGO Office for Nuclear Waste Review). SSM: s utredning föreslår otillräcklig höjning av kärnavfallsavgiften. 2013. http://www.mkg.se/ssmsutredning-foreslar-otillracklig-hojning-av-karnavfall savgiften

24. Swedish Radiation Safety Authority. The Review Process. http://www.stralsakerhetsmyndigheten.se/In-English/ About-the-Swedish-Radiation-Safety-Authority1/ The-site-for-a-spent-nuclear-fuel-repository1/ReviewProcess/

25. Swedish Radiation Safety Authority. Review of the Nuclear Criticality Safety of SKB's Licensing Application for a Spent Nuclear Fuel Repository in Sweden. Technical
Note 2012:65. http://www.stralsakerhetsmyndigheten. se/Global/Publikationer/Rapport/Technical\%20Note/ 2012/SSM-Rapport-2012-65.pdf

26. SKB. Minutes from Public Consultation Meeting, 1st June 2006. http://www.skb.se/Templates/Standard 17139.aspx. 2006

27. MKG (the Swedish NGO Office for Nuclear Waste Review). Protokoll klart från det ferte övergripande avstämningsmötet mellan SSM och SKB. 2013. http:// www.mkg.se/protokoll-klart-fran-det-femte-overgri pande-avstamningsmotet-mellan-ssm-och-skb

28. Swedish Radiation Safety Authority. Avstämningsmöte angående TPP mellan SSM och SKB den 12 november 2013. 2013.http://www.mkg.se/uploads/Arende_SSM2011_37/ SSM201137_045_131112_Avstamningsmote_med_ SKB_om_TPP.pdf

\section{Ulf Rossegger}

\section{ŠVEDIJOS RADIOAKTYVIŲJŲ ATLIEKŲ TVARKYMO PROGRAMOS NUOSTATOS - AR PAVYKSTA IGYVENDINTI?}

\section{Santrauka}

Polemizuojant dèl saugaus ir galutinio radioaktyviųjų atliekų šalinimo būdo, buvo pateiktas ne vienas pasiūlymas. Nors moksliškai dar nèra galutinai pagrịsta, tačiau daugeliui Europos šalių atrodo labiausiai priimtinas būdas - geologiniai atliekynai.

Straipsnio tikslas - atskleisti, kaip organizuojamas radioaktyviụjų atliekų tvarkymas Švedijoje. Darbe akcentuojamas nacionalinès politikos igyvendinimas, atskleidžiama, kokios buvo ịkurtos atsakingos agentūros. Straipsnyje siekiama analizuoti priimtą strategiją ir procesus bei parodyti kylančius sunkumus ieškant radioaktyviụjų atliekų šalinimo vietos, atitinkančios techninius reikalavimus, priimtinos politikams bei visuomenei.

Pateikiama trumpa istorinė apžvalga, bandoma nustatyti išskirtinius etapus iggyvendinant nacionalinę radioaktyviųjų atliekų tvarkymo strategiją. Atskleidžiama, kaip buvo įdiegta Švedijos nacionalinė tiesioginio geologinio šalinimo koncepcija ir kokios buvo taikytos politinès priemonės. Analizuojamas dabartinis radioaktyviųjų atliekų tvarkymo iggyvendinimo etapas.

Raktažodžiai: radioaktyviųjų atliekų tvarkymas, didelio aktyvumo radioaktyvios atliekos, Švedija 
Ульф Россеггер

\section{ЭЛЕМЕНТЫ ШВЕДСКОЙ ПРОГРАММЫ \\ ОБРАЩЕНИЯ С ЯДЕРНЫМИ ОТХОДАМИ - КАК УДАЁТСЯ ЕЁ РЕАЛИЗОВАТЬ?}

Резюме

В дискуссиях о безопасном захоронении ядерных отходов, были выдвинуты многочисленные предложения. Хотя с научной точки зрения ответы не являются окончательными, вариант геологического захоронения, кажется, наиболее распространенным подходом в большинстве европейских стран.

Во-первых, цель этой статьи заключается в представлении организации обращения с ядерными отходами (NWM) в Швеции. Показано, что особое внимание должно уделяться реализации соответствующей национальной политики, а также какие ответственные институции были созданы. Целью статьи также является анализ принятой стратегии и процесса захоронения, а также выявление трудностей, связанных с поиском места захоронения, которое отвечало бы техническим требованиям и получило бы политическое и общественное признание.

После краткого исторического обзора в статье делается попытка определить характерные национальные фазы в развитии обращения с ядерными отходами. Затем показано, как концепция Швеции для прямого геологического захоронения ядерного топлива, была реализована и какие политические меры были приняты. В дополнение к этому проанализировано настоящее положение реализации процесса захоронения.

Ключевые слова: обращение с ядерными отходами, высокоактивные отходы, Швеция 